\title{
The changed occupation and behavioral among imported malaria cases 2009-2011 in Sukabumi District-West Java, Indonesia
}

\author{
Dewi Susanna ${ }^{*}$, Tris Eryando ${ }^{2}$, Dian Pratiwi ${ }^{3}$, Fajar Nugraha $^{4}$ \\ From Challenges in malaria research \\ Basel, Switzerland. 10-12 October 2012
}

\section{Background}

A malaria outbreak occurred in the Sukabumi District in 2004, 785 cases were reported and 8 of them died. The imported cases are sometimes blamed as the trigger of the outbreak. Till now malaria has been endemic in Sukabumi. This research aimed to discover the characteristic of the migrants' cases before and after they had got malaria.

\section{Materials and methods}

The subjects were imported malaria cases that were collected from the Health Center in 4 Sub-district in Sukabumi District for the year 2009 to 2011, and 145 subjects were interviewed in their house using structured questionnaires. The data were analyzed descriptively to describe the distribution of the cases in terms of sex, occupation and the practice in preventing the transmission of malaria.

\section{Results}

The majority of import malaria cases in Sukabumi were male and of productive age (more than 15 years old). They worked mostly in mining, and the rest were in plantation, merchant, and other type of labour or housewives. After they got infected by malaria they went or were sent back to their home land (Sukabumi). After they have got treatment and got well, some of them went back to their previous occupation in the same location and some in different location with the same activity. Few of them did not go back and stay unemployed in their home land.

In relation to the risk factors in malaria transmission, workers who were treated in Sukabumi mostly worked as miners and had experienced night shift, or some of them

${ }^{1}$ Department of Environmental Health, Faculty of Public Health, Universitas Indonesia, Kampus UI Depok, Indonesia 16424

Full list of author information is available at the end of the article
Table 1 The distribution of characteristic malaria import cases in Sukabumi, West Java, Indonesia 2009-2011

\begin{tabular}{|c|c|c|c|}
\hline \multicolumn{2}{|c|}{ Total cases $=145$} & \multirow[b]{2}{*}{ Number } & \multirow[b]{2}{*}{$\%$} \\
\hline Variable & Categories & & \\
\hline \multirow[t]{2}{*}{ Sex } & Male & 139 & $95.9 \%$ \\
\hline & Female & 6 & $4.1 \%$ \\
\hline \multirow[t]{3}{*}{ age } & $<15$ years & 0 & $0.0 \%$ \\
\hline & $15-54$ years & 138 & $95.2 \%$ \\
\hline & $>54$ years & 7 & $4.8 \%$ \\
\hline \multirow[t]{6}{*}{ Occupation (before ill) } & Plantation Growers & 4 & $2.8 \%$ \\
\hline & Merchants & 4 & $2.8 \%$ \\
\hline & Miners & 130 & $89.7 \%$ \\
\hline & Housewives & 2 & $1.4 \%$ \\
\hline & Casual Laborers & 1 & $0.7 \%$ \\
\hline & Other & 4 & $2.8 \%$ \\
\hline \multirow[t]{5}{*}{ Occupation (after ill) } & $\begin{array}{l}\text { Moved out and change of } \\
\text { occupation }\end{array}$ & 35 & $24.1 \%$ \\
\hline & $\begin{array}{l}\text { Moved out and same } \\
\text { occupation }\end{array}$ & 10 & $6.9 \%$ \\
\hline & $\begin{array}{l}\text { Same location and change } \\
\text { of occupation }\end{array}$ & 12 & 8.3 \\
\hline & $\begin{array}{l}\text { Same location and same } \\
\text { occupation }\end{array}$ & 85 & $58.6 \%$ \\
\hline & Unemployed & 3 & $2.1 \%$ \\
\hline \multirow[t]{7}{*}{ Night Behaviors } & Toilet activity & 1 & $0.7 \%$ \\
\hline & Hangout, watch television & 13 & $9.0 \%$ \\
\hline & Patrolling & 5 & $3.4 \%$ \\
\hline & Fishing & 4 & $2.8 \%$ \\
\hline & Night shifts (miners, ojek) & 82 & $56.6 \%$ \\
\hline & No outside activity & 4 & $2.8 \%$ \\
\hline & Other & 13 & $9.0 \%$ \\
\hline \multirow[t]{2}{*}{$\begin{array}{l}\text { The use of mosquito net } \\
\text { and repellent }\end{array}$} & $\begin{array}{l}\text { Use mosquito net and } \\
\text { repellent }\end{array}$ & 85 & $58.6 \%$ \\
\hline & $\begin{array}{l}\text { Do not use mosquito net } \\
\text { and repellent }\end{array}$ & 60 & $41.4 \%$ \\
\hline
\end{tabular}


worked as "ojek" (motorcycle cab) and worked till late at night. Some of them had experienced night activities such as hanging out or watching television and some of them were not aware of malaria transmission. Around $56.6 \%$ used a mosquito net or repellent, and the rest did not take any protection to control malaria transmission.

\section{Conclusion}

The imported malaria cases in Sukabumi were dominated by males of productive age, worked as miners experienced in night shift, without proper protection to avoid malaria transmission and they consistently looked to return to their previous occupation in the same location. So this is important for the district health office either in the home land or the work destination to promote malaria transmission protection among workers.

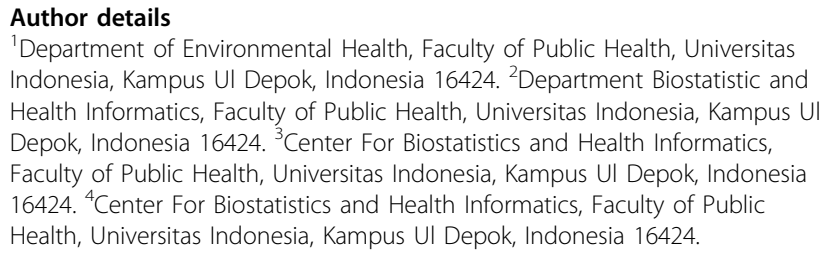

Published: 15 October 2012

\section{Reference}

1. District Health Office: Reports of malaria cases in 2009-2011. Sukabumi District Health Office, Indonesia; 2011.

\section{doi:10.1186/1475-2875-11-S1-P128}

Cite this article as: Susanna et al:: The changed occupation and behavioral among imported malaria cases 2009-2011 in Sukabumi District-West Java, Indonesia. Malaria Journal 2012 11(Suppl 1):P128.

\section{Submit your next manuscript to BioMed Central} and take full advantage of:

- Convenient online submission

- Thorough peer review

- No space constraints or color figure charges

- Immediate publication on acceptance

- Inclusion in PubMed, CAS, Scopus and Google Scholar

- Research which is freely available for redistribution

Submit your manuscript at www.biomedcentral.com/submit 